九州大学学術情報リポジトリ

Kyushu University Institutional Repository

\title{
Dynamic Linkage Between Biomass Energy Consumption and Ecological Footprint: A Panel Analysis for BRICS Countries
}

Shamal Chandra Karmaker

International Institute for Carbon-Neutral Energy Research (WPI-I2CNER) Kyushu University

Hosan, Shahadat

International Institute for Carbon-Neutral Energy Research (WPI-I2CNER) Kyushu University

Md. Matiar Rahman

International Institute for Carbon-Neutral Energy Research (WPI-I2CNER) Kyushu University

Kanchan Kumar Sen

International Institute for Carbon-Neutral Energy Research (WPI-I2CNER) Kyushu University

他

https://doi.org/10.5109/4738556

出版情報: Proceedings of International Exchange and Innovation Conference on Engineering \& Sciences (IEICES). 7, pp. 32-38，2021-10-21. 九州大学大学院総合理工学府

バージョン:

権利関係 : 


\title{
Dynamic Linkage Between Biomass Energy Consumption and Ecological Footprint: A Panel Analysis for BRICS Countries
}

\author{
Shamal Chandra Karmaker ${ }^{1,2,3}$, Shahadat $\operatorname{Hosan}^{1,2}$, Md. Matiar Rahman ${ }^{1,3}$, Kanchan Kumar Sen ${ }^{1,3}$ and Bidyut Baran \\ $\mathrm{Saha}^{1,2^{*}}$ \\ ${ }^{1}$ International Institute for Carbon-Neutral Energy Research (WPI-I2CNER) Kyushu University, 744 Motooka, Nishi-ku, \\ Fukuoka-shi, Fukuoka 819-0395, Japan \\ ${ }^{2}$ Mechanical Engineering Department, Kyushu University, 744 Motooka, Nishi-ku, Fukuoka-shi, Fukuoka 819-0395, \\ Japan \\ ${ }^{3}$ Department of Statistics, University of Dhaka, Dhaka-1000, Bangladesh \\ ${ }^{*}$ Corresponding author email: saha.baran.bidyut.213@m.kyushu-u.ac.jp
}

\begin{abstract}
Biomass energy consumption has become a popular issue among policymakers in recent years due to its environmental repercussions. Biomass is one of the most common traditional easy sources of energy, and various studies have demonstrated its effects to health and the economy. However, there is a paucity of evidence on the use of biomass energy to mitigate climate change. This study explores the relationship between biomass energy consumption and ecological footprint in Bazil, Russia, India, China and South Africa (BRICS) countries during the period of 1990-2017. For this purpose, we employed augmented mean group (AMG) panel data estimator addressing the heterogeneity and problem of cross-sectional dependency in the panel data series. The results indicate that biomass energy consumption raises the ecological footprint of the BRICS nations. Policies are proposed to reduce the negative impact of biomass energy on the environment based on these findings.
\end{abstract}

Keywords: biomass; ecological footprint; BRICS.

\section{INTRODUCTION}

To achieve sustainable development goals, all countries must work closely together in three dimensions: economic, environmental, and social. As a result, environmental safety is a major issue for policymakers worldwide. People in all nations and regions, particularly the poorest and utmost vulnerable, are adversely affected by environmental issues such as global warming, climate change, and air pollution. As a result, immediate efforts and strategies are needed to combat climate change, avoid global warming, and minimize air pollution. One possible answer is to replace fossil fuels, which account for $80 \%$ of worldwide primary energy consumption and $75 \%$ of greenhouse gas emissions, with renewable energy such as biomass, wind, geothermal, and solar energy. The majority of academics agree that using renewable energy helps to reduce carbon emissions and avoid environmental deprivation [1-4]. Renewable energy has recently been developing at a significant rate, owing to energy efficiency improvements, scientific and technical developments, and supportive regulations $[5,6]$.

Biomass is the most abundant renewable energy source on the planet. Bioenergy, including traditional biomass use, generated around $12 \%$ of total final energy consumption in 2018. Modern bioenergy, on the other hand, accounted for over half of all renewable energy and provided $5.1 \%$ of total global final energy consumption $[5,7]$. Biomass energy will play a crucial role in meeting world energy growth over the coming years [8,9]. Bioenergy is expected to be the fastest-growing renewable energy source between 2018 and 2023, according to the International Energy Agency (with a projected growth rate of 30 percent).

As biomass energy becomes more commonly used, it has aroused the interest of numerous academics. A number of research have concentrated on the ecological consequences of biomass energy consumption [10-13], aside from research on investigating the influences of biomass energy use on economic development [14-17], human health [18-21], and human development [22-24].
The majority of these studies have used carbon emissions as a proxy for ecological quality. The key issue is that carbon emissions represent only a minor part of environmental damage [25]. This measure does not account for the overall effect of human actions on the environment. The ecological footprint, established by Wackernagel and Rees [26], is a more robust metric than carbon emissions [27,28]. According to the Global Footprint Network, the Ecological Footprint is the only metric that measures "how much nature we have and how much nature we use" [29]. Furthermore, the ecological footprint may account for both direct and indirect effects of human activity on the atmosphere [30]. As a result, the ecological footprint might be a good metric to use instead of carbon emissions when evaluating ecological efficiency.

The ecological footprint is a term that has recently increased in prominence and is now widely used in environmental studies [31-37]. However, only a few empirical studies [12,38,39] have looked into the connection between biomass energy and environmental footprint. This relationship has been the subject of debate in previous empirical studies. The literature has highlighted both the positive and negative effects of biomass energy use on environment. More precisely, biomass energy use is environmentally friendly, according to one group of researchers, because it reduces greenhouse gas emissions [40], CO2 emissions [10,4144], and the ecological footprint [38]. Another party $[12,13,45,46]$, on the other hand, has argued that biomass energy raises carbon emissions, which is bad for the atmosphere. Therefore, this study investigates the association between biomass energy consumption and ecological footprint in BRICS nations, taking into account the role of gross domestic product (GDP), natural resources, and globalization. We use different econometric techniques in this study, including cross sectional augmented IPS (CIPS) unit root tests, a Westerlund cointegration test, and AMG long-run estimation approach. These methods help account for 
cross-sectional dependency in panel data analysis and provide more accurate performance.

\section{MODEL AND DATA}

\subsection{Econometric model}

Based on the literature review and previous studies $[12,47,48]$, we adopt the following model to explore the relationship between biomass energy use and ecological footprint, using economic growth (GDP), natural resources, and globalization as control variables:

$$
E F_{i t}=f\left(B I O_{i t}, G D P_{i t}, N R_{i t}, G I_{i t}\right)
$$

In equation (Eq.1), EF represents for ecological footprint, BIO stands for biomass energy consumption, GDP stands for economic growth, NR indicates for natural resources, and GI denotes for globalization index. A simple multivariate structure is applied to discover the relationship among all considered variables. Simultaneously, variables are converted in the form of natural logarithm to reduce dispersion and flat the data. The log-linear structure of the model is expressed in equation (Eq.2).

$$
\begin{aligned}
& \ln (E F)_{i t}=\alpha+\beta \ln (B I O)_{i t}+\delta_{1} \ln (G D P)_{i t} \\
& +\delta_{2} \ln (N R)_{i t}+\delta_{3} \ln (G I)_{i t}+\varepsilon_{i t}
\end{aligned}
$$

Where $\mathrm{i}(=1 \ldots \ldots, \mathrm{N}), \mathrm{t}(=1 \ldots \ldots, \mathrm{T})$ indicate the nations and time respectively. $\beta, \delta_{1}, \delta_{2}$ and $\delta_{3}$ denote the coefficients of biomass energy, economic growth, natural resources and globalization index, respectively. $\varepsilon_{i t}$ is the random error and $\alpha$ indicates for intercept. The coefficient $\beta$, which calculates the partial effect of biomass energy consumption on ecological footprint, is the main object of our study.

\subsection{Data}

We use an annual dataset from 1990 to 2017 to examine the connection between biomass energy use and the ecological footprint in the BRICS nations. Data of ecological footprint (gha per capita) have been extracted from the Global Footprint Network [29]. Biomass energy consumpitn (tons per capita) is derived from the UN Environment's Global Material Flows Database [49]. Globalization data is extracted from the KOF Globalization Index [50]. Rest of the control variables are collected from World Development Indicator (WDI), World Bank [51].

\subsection{Methodology}

'Following the 4-step procedure, advanced econometric methods are applied to calculate the longrun coefficient of $\mathrm{Eq}$ (1) in order to determine the influence of biomass energy use on ecological footprint. First, the cross-sectional dependency is confirmed by employing the Breusch and Pagan LM test and the Pesaran CD test. Second, the the stationarity assumptions are investigated using CIPS panel unit root test. If the non-stationarity is verified, the third step uses Westerlund approach to see if there are any cointegrating relationships exists or not. Finally, after confirming that the variables are cointegrated, parameters are calculated using second-generation augmented mean group estimation technique (AMG).

\subsubsection{Cross-sectional dependence tests}

One of the flaws of preceding analytical approaches is the presumption of cross-sectional independence. If cross-sectional dependency is not addressed in the panel data, the study results from such methods can be biased. To address this problem, we conducted cross-sectional dependence tests at the start of the research. LM [52] and CD test [53] are applied to determine the cross-sectional dependence in the current research.

The following equation is used to calculate LM test statistic:

$$
L M^{B P}=T \sum_{i=1}^{N-1} \sum_{j=i+1}^{N} \hat{r}_{i j}^{2}
$$

For the sufficiently large number of T, the LM test is ineffective. Pesaran proposes the following CD test as an alternative to solving this problem:

$$
C D^{P}=\sqrt{\frac{2 T}{N(N-1)}}\left(\sum_{i=1}^{N-1} \sum_{j=i+1}^{N} \hat{r}_{i j}^{2}\right)
$$

In Eq.(3) and Eq.(4) $\hat{r}_{i j}^{2}$ reveals the cross-section correlation of the error.

\subsubsection{Panel unit root test and cointegration test}

Non-stationary variables might lead to erroneous regression findings and hence it is important to verify the stationary properties of the considered variables. The existence of cross-sectional dependency across countries was investigated using Pesaran's [54] cross-sectional augmented IPS (CIPS) test. Before estimating the longrun coefficient, a test of cointegration can be employed to discover the long-run connection within the variables if the series has unit root.We used the Westerlund [55] method at this stage, which address the issue of crosssectional dependency, instead of the cointegration test of Pedroni [56,57] and Kao [58].

\subsubsection{Estimation of long-run coefficients}

After confirming the existence of cointegration among the variables, the estimation of the long-run coefficient can be computed. Coefficients can be calculated employing augmented mean group (AMG) [59] estimation technique in the existence of crosssectional dependency and slope heterogeneity.

The AMG estimator is calculated in 2 phases. First, it uses first difference OLS to combine the unobserved common factor with the time dummies in the following equation:

$$
\Delta Y_{i t}=\alpha_{i}+\beta_{i} \Delta X_{i t}+\phi_{i} f_{t}+\sum_{t=2}^{T} \theta_{t} D U M M Y_{t}+\varepsilon_{i t}
$$

where $\Delta$ uses as a difference operator, $\alpha_{i}$ indicates the constant, $X_{i t}$ and $Y_{i t}$ are the predictor and outcome variables respectively, $\beta_{i}$ represents the slope of every cross-section, and $\varepsilon_{i t}$ represents random error.

Second, the cross-section model parameters are averaged over the panel. 


$$
A M G=\frac{1}{N} \sum_{i=1}^{N} \tilde{\beta}_{i}
$$

\section{RESULTS AND DISCUSSION}

The findings for the entire sample are presented in this section. Table 1 displays the cross-section dependency results. Based on the related p-values of LM and $\mathrm{CD}$ test statistics, we may reject the null hypothesis of cross-section independence for ecological footprint, biomass energy use, economic growth, natural resources, and globalization index. As a result, all variables in this study have cross-section dependence.

Table 1. Cross-sectional dependence test.

\begin{tabular}{lll|ll}
\hline \multirow{2}{*}{ Variables } & \multicolumn{2}{c|}{ LM } & \multicolumn{2}{c}{ CD } \\
\cline { 2 - 5 } & Statistic & p-value & Statistic & p-value \\
\hline $\operatorname{lnEF}$ & 47.71 & 0.000 & 3.15 & 0.000 \\
$\ln$ IIO & 61.31 & 0.000 & 5.55 & 0.000 \\
$\operatorname{lnGDP}$ & 228.29 & 0.000 & 15.05 & 0.000 \\
$\ln$ lnR & 127.37 & 0.000 & 10.92 & 0.000 \\
$\operatorname{lnGI}$ & 269.96 & 0.000 & 16.43 & 0.000 \\
\hline
\end{tabular}

It is necessary to determine if data are unit-roots before evaluating cointegration. CIPS was used in this analysis to detect the presence of unit roots in the variables. Table 2 provides a summary of the test findings. As a result of the CIPS test, all five variables appear to be I (1).

Table 2. Panel unit root test.

\begin{tabular}{lcl}
\hline \multirow{2}{*}{ Variables } & \multicolumn{2}{c}{ ClPS test } \\
\cline { 2 - 3 } & Level & 1st difference \\
\hline $\ln E F$ & -0.069 & $-4.739^{* * *}$ \\
$\ln B I O$ & $-2.310^{*}$ & $-4.519^{* * *}$ \\
$\operatorname{lnGDP}$ & $-2.495^{*}$ & $-3.226^{* * *}$ \\
$\ln \mathrm{NR}$ & -1.395 & $-4.086^{* * *}$ \\
$\operatorname{lnGI}$ & $-2.544^{*}$ & $-2.293^{* * *}$ \\
\hline
\end{tabular}

Significance level $\left({ }^{*} 10 \%{ }^{* *} 5 \%,{ }^{* * *} 1 \%\right)$.

Westerlund panel cointegration tests were used to find the long-run connection among variables in Eq. (1). The null hypothesis in this test is that the panel has no cointegration. Table 3 shows that there is a long-run relationship among the considered variables, rejecting the null hypothesis at the $5 \%$ level.

Table 3. Panel cointegration tests.

\begin{tabular}{|c|c|c|}
\hline Westerlund (2005) & t-statistic & p-value \\
\hline Variance ratio & -1.5354 & 0.0423 \\
\hline
\end{tabular}

After establishing a long-run association among variables, the coefficients in Eq (1). were estimated using augmented mean group (AMG) technique. Table 4 shows the estimated coefficients and p-values for the related predictor variables with ecological footprint as the regressed variable $(\operatorname{lnEF})$

Table 4. AMG long run coefficient estimation.

\begin{tabular}{|c|c|c|c|}
\hline Variables & Coefficient & Std. error of coefficient & p-value \\
\hline $\ln$ BIO & 0.1358 & 0.1224 & 0.0268 \\
\hline $\ln$ GDP & 0.7044 & 0.0888 & 0.000 \\
\hline $\ln$ RR & 0.0193 & 0.0249 & 0.438 \\
\hline $\ln \mathrm{II}$ & -0.1737 & 0.0509 & 0.001 \\
\hline
\end{tabular}

The influence of biomass energy usage on the environment is a major concern. Results in Table 4 suggest that biomass energy use have a statistically significant positive influence on ecological footprint; for instance, a 1 percent upsurge in biomass energy consumption rises ecological footprint by 0.14 percent on average for the BRICS countries. This result backs up claims and findings from a large body of research that biomass energy consumption degrades environment. However, increasing the efficiency of biomass energy 
production will support to shrink costs, promoting the usage of biomass energy as a substitute for fossil fuels. As a result, a major growth in biomass energy production might help reduce reliance on fossil fuels while also addressing ecological issues [60]. Furthermore, food crops and hydrocarbon-rich plants are the primary sources of biomass for energy generation [61]. The expansion of these sources absorbs $\mathrm{CO}_{2}$, which is the main cause of climate change. These advantages, however, are insufficient to compensate for the negative effects of biomass energy extraction on ecologies in the BRICS nations. Soil abrasion, nutrient depletion, deforestation, water amount and quality deprivation, and land rivalry are all problems that may arise from the cultivation of energy crops. Furthermore, biomass harvesting and combustion may have negative environmental implications. Although the environmental effects of biomass energy use in the BRICS nations are still being debated [11,62,63], our empirical findings are an effort to draw the attention of BRICS policymakers to the detrimental effects of biomass energy consumption. Figure 1 depicts long-run relationship and their directions.

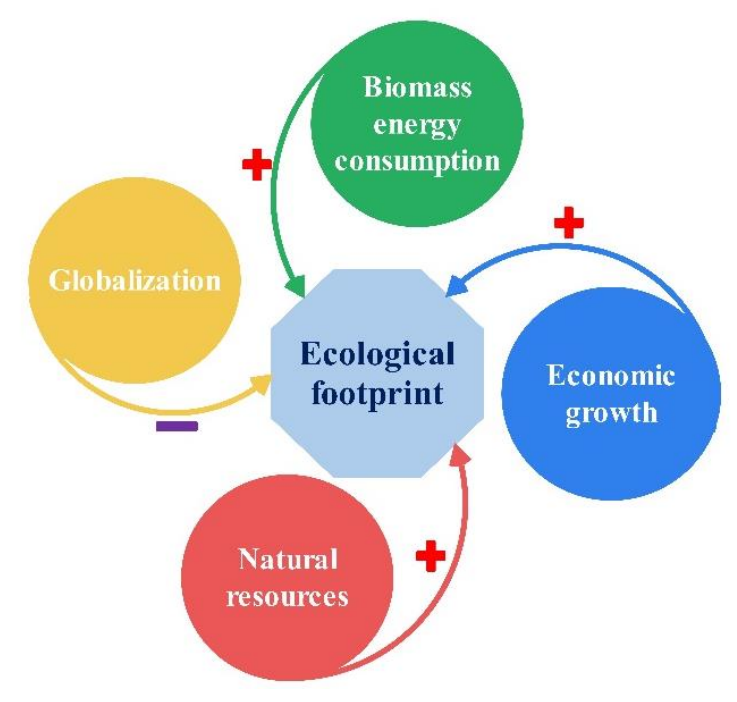

Fig 1. Graphic long-run relationships with ecological footprint.

\section{CONCLUSIONS \\ IMPLICATIONS \\ AND POLICY}

This study investigates the connection between biomass energy use and ecological footprint in BRICS nations from 1990 to 2017, taking natural resources and globalization into account. In this paper we employed second generation unit root tests, Westerlund cointegration approach and AMG estimator to diagnose the causal relationship between underlying variables. The findings suggest that biomass energy use has a positive influence on the ecological footprint. On the contrary, globalization reduce the ecological footprint for the BRICS nations.

Some policy guidelines for BRICS countries are proposed based on these empirical findings. Biomass energy can be a driver of economic development in these countries [62,64], but it devastates the environment. As a result, reducing biomass energy extraction could help BRICS countries improve environmental quality. Policymakers in these nations can focus on other renewable energy sources, such as wind and solar, which have less adverse environmental repercussions.

\section{REFERENCES}

[1] Pata UK. Linking renewable energy, globalization, agriculture, $\mathrm{CO} 2$ emissions and ecological footprint in BRIC countries: A sustainability perspective. Renew Energy
2021;173:197-208.

https://doi.org/10.1016/j.renene.2021.03.125.

[2] Yurtkuran S. The effect of agriculture, renewable energy production, and globalization on $\mathrm{CO} 2$ emissions in Turkey: A bootstrap ARDL approach. Renew Energy 2021;171:1236-45. https://doi.org/10.1016/j.renene.2021.03.009.

[3] Flores-Granobles M, Saeys M. Minimizing CO2emissions with renewable energy: A comparative study of emerging technologies in the steel industry. Energy Environ Sci 2020;13:1923-32. https://doi.org/10.1039/d0ee00787k.

[4] Haldar A, Sethi N. Effect of institutional quality and renewable energy consumption on $\mathrm{CO} 2$ emissions-an empirical investigation for developing countries. Environ Sci Pollut Res 2021;28:15485-503. https://doi.org/10.1007/s11356-020-11532-2.

[5] REN21. Renewables 2020 Global Status Report. 2020.

[6] Karmaker SC, Hosan S, Chapman AJ, Saha BB. The role of environmental taxes on technological innovation. Energy 2021;232:121052. https://doi.org/10.1016/j.energy.2021.121052.

[7] Rahman MM, Hosan S, Karmaker SC, Chapman AJ, Saha BB. The effect of remittance on energy consumption: Panel cointegration and dynamic causality analysis for South Asian countries. Energy 2021;220:119684 https://doi.org/10.1016/j.energy.2020.119684.

[8] Bilgili F, Koçak E, Bulut Ü, Kuşkaya S. Can biomass energy be an efficient policy tool for 
sustainable development? Renew Sustain Energy Rev 2017;71:830-45. https://doi.org/10.1016/j.rser.2016.12.109.

[9] Güney T, Kantar K. Biomass energy consumption and sustainable development. Int $\mathbf{J}$ Sustain Dev World Ecol 2020;27:762-7. https://doi.org/10.1080/13504509.2020.1753124

[10] Danish, Wang Z. Does biomass energy consumption help to control environmental pollution? Evidence from BRICS countries. Sci Total Environ 2019;670:1075-83. https://doi.org/10.1016/j.scitotenv.2019.03.268.

[11] Danish. Nexus between biomass energy consumption and environment in OECD countries: a panel data analysis. Biomass Convers $\quad$ Biorefinery 2021. https://doi.org/10.1007/s13399-020-01256-1.

[12] Wang Z, Bui Q, Zhang B, Pham TLH. Biomass energy production and its impacts on the ecological footprint: An investigation of the G7 countries. Sci Total Environ 2020;743:140741. https://doi.org/10.1016/j.scitotenv.2020.140741.

[13] Mahmood N, Wang Z, Yasmin N, Manzoor W, Rahman A ur. How to bend down the environmental Kuznets curve: the significance of biomass energy. Environ Sci Pollut Res 2019;26:21598-608.

https://doi.org/10.1007/s11356-019-05442-1.

[14] Aydin M. The effect of biomass energy consumption on economic growth in BRICS countries: A country-specific panel data analysis. Renew Energy 2019;138:620-7. https://doi.org/10.1016/j.renene.2019.02.001.

[15] Ajmi AN, Inglesi-Lotz R. Biomass energy consumption and economic growth nexus in OECD countries: A panel analysis. Renew Energy 2020;162:1649-54. https://doi.org/10.1016/j.renene.2020.10.002.

[16] Gao J, Zhang L. Does biomass energy consumption mitigate $\mathrm{CO} 2$ emissions? The role of economic growth and urbanization: evidence from developing Asia. J Asia Pacific Econ 2021;26:96-115.

https://doi.org/10.1080/13547860.2020.1717902

[17] Destek MA. Biomass energy consumption and economic growth: Evidence from top 10 biomass consumer countries. Energy Sources, Part B Econ Plan Policy 2017;12:853-8. https://doi.org/10.1080/15567249.2017.1314393

[18] Tripathi CB, Baredar P, Tripathi L. Air pollution in Delhi: Biomass energy and suitable environmental policies are sustainable pathways for health safety. Curr Sci 2019;117:1153-60. https://doi.org/10.18520/cs/v117/i7/1153-1160.

[19] Corrieri U. Le biomasse legnose non sono vere energie rinnovabili e il loro uso causa gravi effetti sulla salute. Epidemiol Prev 2019;43:300 4. https://doi.org/10.19191/EP19.4.P300.081.

[20] Weldu YW. Life cycle human health and ecosystem quality implication of biomass-based strategies to climate change mitigation. Renew Energy

2017;108:11-8. https://doi.org/10.1016/j.renene.2017.02.046.

[21] Singha B, Eljamal O. A Review on Water Conservation and Consumption Behavior: Leading Issues, Promoting Actions, and Managing the Policies. Proc Int Exch Innov Conf Eng Sci 2020;6:171-8. https://doi.org/10.5109/4102484.

[22] Shamal Chandra Karmaker, Md. Matiar Rahman, Hosan S, Bidyut Baran Saha. The Impact of Biomass Energy Consumption on Human Development: Evidence from Asian Countries. Proc Int Exch Innov Conf Eng Sci 2020;6:204-11.

https://doi.org/10.5109/4102489.

[23] Karmaker SC, Hosan S, Saha BB. Does biomass energy consumption improve human development? Evidence from South Asian countries. Int Energy J 2021;21:81-92.

[24] Wang Z, Bui Q, Zhang B. The relationship between biomass energy consumption and human development: Empirical evidence from BRICS countries. Energy 2020;194:116906. https://doi.org/10.1016/j.energy.2020.116906.

[25] Al-Mulali U, Ozturk I. The effect of energy consumption, urbanization, trade openness, industrial output, and the political stability on the environmental degradation in the MENA (Middle East and North African) region. Energy 2015;84:382-9.

https://doi.org/10.1016/j.energy.2015.03.004.

[26] Wackernagel, M., Rees W. Our ecological footprint: reducing human impact on the earth. New Society Publishers.; 1995.

[27] Ahmed Z, Wang Z. Investigating the impact of human capital on the ecological footprint in India: An empirical analysis. Environ Sci Pollut Res 2019;26:26782-96. https://doi.org/10.1007/s11356-019-05911-7.

[28] Liu T, Wang HZ, Wang HZ, Xu H. The spatiotemporal evolution of ecological security in China based on the ecological footprint model with localization of parameters. Ecol Indic 2021;126.

https://doi.org/10.1016/j.ecolind.2021.107636.

[29] Global Footprint Network; 2020. 2020 n.d. https://www.footprintnetwork.org/.

[30] Ulucak R, Bilgili F. A reinvestigation of EKC model by ecological footprint measurement for high, middle and low income countries. J Clean Prod 2018; 188:144-57. https://doi.org/10.1016/j.jclepro.2018.03.191.

[31] Ahmed Z, Zafar MW, Ali S, Danish. Linking urbanization, human capital, and the ecological footprint in G7 countries: An empirical analysis. Sustain Cities Soc 2020;55:102064. https://doi.org/10.1016/j.scs.2020.102064.

[32] Alola AA, Bekun FV, Sarkodie SA. Dynamic impact of trade policy, economic growth, fertility rate, renewable and non-renewable energy consumption on ecological footprint in Europe. Sci Total Environ 2019;685:702-9. https://doi.org/10.1016/j.scitotenv.2019.05.139.

[33] Destek MA, Sinha A. Renewable, nonrenewable energy consumption, economic growth, trade openness and ecological footprint: 
Evidence from organisation for economic Cooperation and development countries. J Clean Prod 2020;242:118537. https://doi.org/10.1016/j.jclepro.2019.118537.

[34] Nathaniel S, Anyanwu O, Shah M. Renewable energy, urbanization, and ecological footprint in the Middle East and North Africa region. Environ Sci Pollut Res 2020;27:14601-13. https://doi.org/10.1007/s11356-020-08017-7.

[35] Danish, Hassan ST, Baloch MA, Mahmood N, Zhang JW. Linking economic growth and ecological footprint through human capital and biocapacity. Sustain Cities Soc 2019;47:101516. https://doi.org/10.1016/j.scs.2019.101516.

[36] Saud S, Chen S, Danish, Haseeb A. Impact of financial development and economic growth on environmental quality: an empirical analysis from Belt and Road Initiative (BRI) countries. Environ Sci Pollut Res 2019;26:2253-69. https://doi.org/10.1007/s11356-018-3688-1.

[37] Yilanci V, Korkut Pata U. Convergence of per capita ecological footprint among the ASEAN-5 countries: Evidence from a non-linear panel unit root test. Ecol Indic 2020;113:106178. https://doi.org/10.1016/j.ecolind.2020.106178.

[38] Bilgili F, Ulucak R. The Nexus Between Biomass - Footprint and Sustainable Development. Encycl Renew Sustain Mater 2020:175-92. https://doi.org/10.1016/b978-012-803581-8.10600-9.

[39] Sarkodie SA, Strezov V, Weldekidan H, Asamoah EF, Owusu PA, Doyi INY. Environmental sustainability assessment using dynamic Autoregressive-Distributed Lag simulations-Nexus between greenhouse gas emissions, biomass energy, food and economic growth. Sci Total Environ 2019;668:318-32. https://doi.org/10.1016/j.scitotenv.2019.02.432.

[40] Baležentis T, Streimikiene D, Zhang T, Liobikiene G. The role of bioenergy in greenhouse gas emission reduction in $\mathrm{EU}$ countries: An Environmental Kuznets Curve modelling. Resour Conserv Recycl 2019;142:225-31.

https://doi.org/10.1016/j.resconrec.2018.12.019.

[41] Bilgili F, Koçak E, Bulut Ü, Kuşkaya S. Can biomass energy be an efficient policy tool for sustainable development? Renew Sustain Energy Rev 2017;71:830-45 https://doi.org/10.1016/j.rser.2016.12.109.

[42] Danish, Ulucak R. Linking biomass energy and $\mathrm{CO} 2$ emissions in China using dynamic Autoregressive-Distributed Lag simulations. J Clean Prod 2020;250:119533. https://doi.org/10.1016/j.jclepro.2019.119533.

[43] Dogan E, Inglesi-Lotz R. Analyzing the effects of real income and biomass energy consumption on carbon dioxide (CO2) emissions: Empirical evidence from the panel of biomass-consuming countries. Energy 2017;138:721-7. https://doi.org/10.1016/j.energy.2017.07.136.

[44] Shahbaz M, Balsalobre-Lorente D, Sinha A. Foreign direct Investment-CO 2 emissions nexus in Middle East and North African countries: Importance of biomass energy consumption. J
Clean Prod 2019;217:603-14. https://doi.org/10.1016/j.jclepro.2019.01.282.

[45] Adewuyi AO, Awodumi OB. Biomass energy consumption, economic growth and carbon emissions: Fresh evidence from West Africa using a simultaneous equation model. Energy 2017;119:453-71.

https://doi.org/10.1016/j.energy.2016.12.059.

[46] Solarin SA, Al-Mulali U, Gan GGG, Shahbaz M. The impact of biomass energy consumption on pollution: evidence from 80 developed and developing countries. Environ Sci Pollut Res 2018;25:22641-57.

https://doi.org/10.1007/s11356-018-2392-5.

[47] Dogan E, Ulucak R, Kocak E, Isik C. The use of ecological footprint in estimating the Environmental Kuznets Curve hypothesis for BRICST by considering cross-section dependence and heterogeneity. Sci Total Environ 2020;723:138063.

https://doi.org/10.1016/j.scitotenv.2020.138063.

[48] Ulucak R, Bilgili F. A reinvestigation of EKC model by ecological footprint measurement for high, middle and low income countries. J Clean Prod 2018;188:144-57. https://doi.org/10.1016/j.jclepro.2018.03.191.

[49] UN Environment Programme International Resource Panel Global Material Flows Database. https://www.resourcepanel.org/global-materialflows-database. 2019.

[50] Gygli S, Haelg F, Potrafke N, Sturm JE. The KOF Globalisation Index - revisited. Rev Int Organ 2019;14:543-74. https://doi.org/10.1007/s11558-019-09344-2.

[51] World B. Data Bank: World Development Indicators 2020. https://databank.worldbank.org/source/worlddevelopment-indicators.

[52] Breusch TS, Pagan AR. The Lagrange Multiplier Test and its Applications to Model Specification in Econometrics. Rev Econ Stud 1980;47:239. https://doi.org/10.2307/2297111.

[53] Pesaran MH. General Diagnostic Tests for Cross Section Dependence in Panels. Univ Cambridge USC 2004;3:Working Paper No.0435, June 2004.

[54] Pesaran MH. A simple panel unit root test in the presence of cross-section dependence. J Appl Econom 2007;22:265-312. https://doi.org/10.1002/jae.951.

[55] Westerlund J. New simple tests for panel cointegration. Econom Rev 2005;24:297-316. https://doi.org/10.1080/07474930500243019.

[56] Pedroni P. Panel cointegration: Asymptotic and finite sample properties of pooled time series tests with an application to the PPP hypothesis. Econom Theory 2004;20:597-625. https://doi.org/10.1017/S0266466604203073.

[57] Pedroni P. Critical Values for Cointegration Tests in Heterogeneous Panels with Multiple Regressors. Oxf Bull Econ Stat 1999;61:653-70. https://doi.org/10.1111/1468-0084.61.s1.14.

[58] Kao C. Spurious regression and residual-based tests for cointegration in panel data. $\mathrm{J}$ Econom 1999;90:1-44. https://doi.org/10.1016/S0304- 
4076(98)00023-2.

[59] Pesaran MH. Estimation and inference in large heterogeneous panels with a multifactor error structure. Econometrica 2006;74:967-1012. https://doi.org/10.1111/j.14680262.2006.00692.x.

[60] Danish, Ulucak R. Linking biomass energy and $\mathrm{CO} 2$ emissions in China using dynamic Autoregressive-Distributed Lag simulations. J Clean Prod 2020;250:119533. https://doi.org/10.1016/j.jclepro.2019.119533.

[61] Abbasi T, Abbasi SA. Biomass energy and the environmental impacts associated with its production and utilization. Renew Sustain Energy Rev 2010;14:919-37. https://doi.org/10.1016/j.rser.2009.11.006.

[62] Destek MA, Aslan A. Disaggregated renewable energy consumption and environmental pollution nexus in G-7 countries. Renew Energy 2020;151:1298-306.

https://doi.org/10.1016/j.renene.2019.11.138.

[63] Shahbaz M, Balsalobre D, Shahzad SJH. The Influencing Factors of $\mathrm{CO} 2$ Emissions and the Role of Biomass Energy Consumption: Statistical Experience from G-7 Countries. Environ Model Assess 2019;24:143-61. https://doi.org/10.1007/s10666-018-9620-8.

[64] Bilgili F, Ozturk I. Biomass energy and economic growth nexus in G7 countries: Evidence from dynamic panel data. Renew Sustain Energy Rev 2015;49:132-8. https://doi.org/10.1016/j.rser.2015.04.098. 